\title{
The Impact of Low Health Literacy to Social Relationship of the People Living with HIV/AIDS
}

\author{
Rinikso Kartono \\ University of Muhammadiyah \\ Malang \\ rinikso@gmail.com
}

\author{
Latipun \\ University of Muhammadiyah \\ Malang \\ lativ_un1@yahoo.com
}

\author{
Abdulkadir Raharjanto \\ University of Muhammadiyah \\ Malang \\ rahardjanto@gmail.com
}

\begin{abstract}
The development of HIV/AIDS is not only caused by virus, but also by the low health literacy. The low health literacy can also lead to various social problems including impeding the people living with HIV/AIDS (PLWHA) social relationship. This study aims to describe 1) The cause of low health literacy in PLWHA and 2) The impact of low health literacy on PLWHA social relations. This study used qualitative approach, and used interview and observation by Focus Group Discussion (FGD) as data collection techniques. Meanwhile, the subjects of this study are PLWHA and Peer Support Groups.This study found that (1) the low health literacy is caused by low education, myths, HIV/AIDS knowledge dissemination and uneven communication system, and the contents of the message in an inappropriate campaign of HIV/AIDS, and (2) the impact of low health literacy is the disruption of PLWHA social relations because they will isolate themselves to be paranoid, self-stigmatized, nonself-disclosure, more aggressive-destructive, vengeful, and unconsciously infecting HIV to others.
\end{abstract}

Keywords: literacy, PLWHA, HIV, social relation.

\section{INTRODUCTION}

Globally, up to 2016, people living with HIV / AIDS (PLWHA) reaches 36.7 million [1]. Meanwhile, in 2016, Indonesia had 48000 (43 000 52 000) new HIV infections and 38000 (34 000 - 43 000) AIDS related to deaths. There were 620000 (530 000 - 730 000) people living with HIV in 2016, [2]. According to Kartono, [3] one of the factors causing the development of HIV transmission is the risky behavior. This behavior occurs due to a person's low literacy. Kartono [4] revealed that the occurrence of low literacy about HIV/AIDS in some Indonesian people due to lack of information, misconceptions, and many myths about HIV/AIDS considers HIV/AIDS as a cursed disease, the disease of western people, or a disease that can be infected through sweat, toothpicks, bath together, and many more.

There are many consequences of Poor Health Literacy on the Treatment of PLWHA. They are: (a) perceiving low self-efficacy dealing with their health conditions; (b) unwilling to get involved in the provision of care; (c) showing larger risks of hospitalization; and (d) being unaware to well-being determinants. [5]. According to Kickbuschi [6], people's inability to read and write is vulnerable to get infected by the virus. Kickbusch [7] states that the impact of weak health literacy has resulted in less healthy choices, riskier behavior, poorer health, less self-management, and barriers accessing health care systems.

Weiss, at all. [8] explained that patients with low literacy have less awareness in taking preventive measures, their health condition, and lack of understanding of care instructions than patients with adequate health literacy. People who have limited health literacy tend to exhibit less healthy behaviors and more frequent hospitalizations $[9,10,11]$.

Kalichman et al. [12,13] found that PLWHA with low literacy are lack of understanding of disease and treatment compared with PLWHA with adequate literacy. Patients with low literacy levels are three times more likely to be non-adherent taking antiretroviral regimens than those with adequate health literacy.

It is very important for PLWHA to have adequate health literacy due to many low literacy impacts. HIV/AIDS literacy is an 'appropriate knowledge' about HIV and drugs or medication. [14]. HIV/AIDS literacy is the capacity of individuals and/or communities to learn, understand basic information, use information, prevent HIV/AIDS, and improve the welfare, mental and social life of PLWHA. [15]

The adequacy of health literacy also has an impact on PLWHA in adherence to antiretroviral treatment and improved health status, which can run a norm more daring disclosure of HIV status of life. $[11,16,17]$. 
Corless, at all [18], found factors affecting HIV and health literacy. The first factor is individual's lack of basic knowledge, wrong knowledge and belief, behavior problem, and socio-economics factor. The second factor is the HIV education system.

The objectives of the study are to explore and describe the cause and effect of low health literacy on the social relations of people living with HIV/AIDS. The result of the study is recommendations for policy makers, especially health department of local government and local AIDS commission.

\section{METHOD}

This study used descriptive qualitative approach. This approach was to find out how PLWHA experience cause and effect of low literacy in East Java, Indonesia. This research was conducted from January to May 2018.

This study used purposive sampling to select the research subject. The subject is newly HIV-infected teenagers and adolescents.

The data collection was done by in-depth interview to obtain understanding and experience of PLWHA. Interviews were conducted by giving unstructured questions. Observation was used to know the PLWHA's social relationships with family, friends, and neighbors. FGD was also used to supplement data.

After the data were collected, then researchers conducted data reduction by selecting data that are relevant to the purpose of research. From the selected data, then they made categorization and described emic, discussed research findings, and formulated conclusions.

\section{RESULT}

Low education is one of the causes of low health literacy, especially HIV/AIDS literacy. This is as stated by NI (HIV/AIDS sufferer) as follows:

"I do not know what HIV/AIDS is, Sir. I also do not know if it is contagious. I just graduated from elementary school; I am so stupid, Sir. When I was positively diagnosed to be infected HIV/AIDS by a doctor, I still do not understand."

Besides NI, another low education subject is Mr. ST. Mr. ST did not graduate from elementary school. He does not know about HIV/AIDS. The disease he suffered is considered a witchcraft. This is ST's statement:

"I am a person who did not graduate from elementary school. I cannot read and write both. When I was infected by HIV/AIDS, my body was full of itch and ulcers. I thought it's a witchcraft. I met a shaman for help, but it did not heal. Then, I went to the doctor. The doctor said I was infected by AIDS. "

There are a lot of misconceptions about HIV/AIDS because of myths. Like the subject of research named RH who assumes that HIV/AIDS is a disease caused by God's curse. RH says:

"Yes. People say that HIV/AIDS is God's cursed disease. And I believe it, especially when I was a drug user."

HS as a senior PLWHA in Malang also considers his disease as a curse from God. This is his statement:

"Yes. I think AIDS is a punishment of God. I did wrong doing like stealing, drug abuse, and free sex. I have many sins so that the God is angry to me. "

Many HIV/AIDS prevention campaigns provide inaccurate information that leads to stigmatization and fear, as it is experienced by $\mathrm{NN}$ :

"HIV/AIDS danger campaign shows PLWHA's images that are in terrible condition. So, they scare me because people infected by HIV will be like that."

Inaccurate information is also experienced by Mrs. MY when she watched a TV show that aired PLWHA from Africa whose condition is terrible. It aired HIV/AIDS as a terrible and frightening disease. This is her statement:

"Previously, I did not understand at all what HIV/AIDS is. I know HIV/AIDS from TV. There is a thin PLWHA and the condition is terrible. I am feared."

Limited access to information about HIV/AIDS also causes low health literacy. Although in the information age, lower-class and rural communities are not all able to access information about HIV/AIDS, as STI states below:

"I am a villager. If I want to know about HIV/AIDS, what should I do, Sir? Thinking of HIV/AIDS never crosses in mind. I know about HIV after being infected. Health workers have never been informed about HIV/AIDS.

The problem of information access is also related to limited information media in rural areas such as limited internet access or too expensive fees. So, people cannot access information about HIV/AIDS through internet. This is as ALX states:

"I heard that HIV/AIDS is from villagers only.

That is not true at all. Now accessing information about HIV/AIDS is easy via the internet. Unfortunately, there is no internet access in the village."

Low health literacy will affect the PLWHA's social relationship. They will limit their social relations or isolate themselves. This is as HS states:

"For two years I was isolating myself at home.

I was so afraid that there were neighbors or 
friends who knew my status. I also quit my job. I am afraid if the boss knew it and I was expelled."

The act of isolating itself has been also done by HS. He is afraid if his neighbors who know his condition will insult his family, as he states below:

"Once I know I am HIV infected, I am afraid to go out as my neighbor knows it. This can insult the honor of parents, Sir. "

Excessive and unreasonable fears are often experienced by PLWHA. The subject of research named NI is always fearful and suspicious, if anyone staring at him. Here he says:

"If anyone sees me, I feel that they know my disease, but they don't. This feeling is hard to bear, so I don't want to meet others and I isolate myself to connect with others."

Excessive fear of people living with HIV also occurs in the workplace. This is experienced by Mrs. STI as her statement says:

"After I am infected by HIV/AIDS, I became a paranoid, Sir. I'm scared when people see me. Whereas the reality is not so."

HIV/AIDS does not always make people worse. Due to lack of knowledge, it makes PLWHA feel themselves bad, like feeling to die soon, hard to get a job or a mate. This assumption is experienced by BB as follows:

"A person like me is like other who respond it bad, Sir. Being PLWHA is definitely bad. My body gets worse because it cannot work well. Until now, I am afraid of not finding a mate. I do not feel that I can be a mate."

Low literacy can also cause the non-self-disclose PLWHA to their partners. They are usually afraid of being left behind or divorced. As a result, they infect the disease to their husband/wife. It is as stated by ALX:

"I am afraid to tell my second husband that I am infected by HIV. I am afraid he will leave me behind or divorce me. Two years ago, my husband was positively infected by HIV. It must be because of me."

The divorce reason is also the reason for a research subject named Mrs. MY, a non-selfdisclosure. She is afraid of being divorced, and discriminated by her family. Facing the problem makes me feel stressed, as she states below:

"If I tell my illness, I am afraid of being divorced my husband. I am also afraid to be known by family and society. They can stigmatize and discriminate me. Facing such situation makes me stress sir."

Behavioral changes become aggressive after being infected by HIV/AIDS is also experienced by RH. This young man always gets angry to anyone who knows it. This is what he says:
"I am sensitive, Sir. If anyone stares at me, I scold or even hit them. In my mind, why they are staring at me constantly. I feel offended."

\section{DISCUSSION}

The results of this study explains the cause and effect of low health literacy especially about HIV/AIDS literacy. This study finds the cause of low literacy is due to low education, in which knowledge about HIV/AIDS is based on the myths. These findings confirm the findings of previous studies, such as Corless, at all [18], who found the cause of low-health literacy is a lack of basic knowledge, incorrect knowledge and beliefs, behavioral issues, socio-economics factors and HIV education service providers. Unfortunately, some studies have not made it clear that health literacy through HIV/AIDS prevention campaigns can be counterproductive if the material is not appropriate [19]. The results of this study also find that the campaign containing material images of the PLWHA body is bad and cause fear. So, low literacy can also be caused by poor health literacy content.

Researchers have studied the effects of low literacy on HIV/AIDS. They find a low health literacy impact on low health status, risky behavior, treatment seeking, adherence to antiretroviral therapy, and the difficulty of accessing treatment services [5-13]

This research also explains the impact of low health literacy on PLWHA social relations. The results of this study show that the low health literacy can be a constraint of PLWHA social relationships with their partners, family, friends, neighbors, and the community. This is because PLWHA's low health literacy will do the self-isolation. If PLWHA has sufficient health literacy, then it will not do this. Kartono [2] found that PLWHA is more empowered, open, and socially concerned with obtaining educational information from peer support group.

This study also found that low literacy will damage social relationships because PLWHA experience paranoid, self-stigma, non-self-disclosure, aggressive, vengeful, violent, and transmit HIV to others.

\section{CONCLUSION}

The results of this study have confirmed the results of other studies on low health literacy especially for PLWHA. This study also found some novelties. First, the low health literacy for PLWHA is caused by the spread of HIV/AIDS knowledge and 
communication system which are uneven. Second, the content of messages in HIV/AIDS prevention campaigns is inaccurate and leads to misconception.

The results of this study also found that the low health literacy could damage the PLWHA social relationships. This is because PLWHA will isolate themselves from interacting with others, experiencing paranoia when seen by others, self-stigma, and nonself-disclosure. In addition, PLWHA's behavior also

\section{REFERENCES}

[1] UNAIDS DATA, 2017 , http://www.unaids.org/sites/default/files/media_asset/ 2017_data-book_en.pdf. [cited 2018 Pebruari 16]

[2] UNAIDS Country Indonesia, 2017, http://www.unaids.org/en/regionscountries/countries/i ndonesia [cited 2018 Pebruari 16]

[3] Kartono, Rinikso, Ketidakberdayaan Orang Dengan HIV/AIDS di Kota Malang, Sosiokonsepsia, Vol 16 No. 03, pp. 295-313.2011.

[4] Kartono, Rinikso, Dukungan Sosial Berbasis Kelompok Dukungan Sebaya Dalam Mengatasi Ketidakberdayaan Orang Dengan HIV/AIDS, Sosiokonsepsia, Vol 18 No. 01, pp. 89-109.2013.

[5] McCaffery KJ, Smith SK, Wolf M. The challenge of shared decision making among patients with lower literacy: a framework for research and development. Med Decis Making. 2010;30(1):35-44. Doi:10.1177/0272989X09342279

[6] Kickbuschi J. Health literacy - Addressing the gender issue. International J. health 2(1).2005.

[7] Kickbuschi, Ilona Jürgen M. Pelikan, Franklin Apfel \& Agis D. Tsouros (editor) Health literacy, The solid facts, Denmark, WHO Regional Office for Europe Publication 2013; 1

[8] Schenker, I Inon, HIV/AIDS and literacy: an essential component in Education for All, UNESCO. NY.2005.

[9] Weiss, Barry D, at all,Removing barriers to better, safer care Health literacy and patient safety: Help patients understand, Washington DC, American Medical Association Foundation and American Medical Association.2012.

[10] S. C. Kalichman and D. Rompa, Functional health literacy is associated with health status and healthrelated knowledge in people living with HIV-AIDS," Journal of Acquired Immune Deficiency Syndromes, vol. 25, no. 4, pp. 337-344.2000.

[11] [S. C. Kalichman and D. Rompa, "Emotional reactions to health status changes and emotional wellbeing among HIV-positive persons with limited reading literacy," Journal of Clinical Psychology in Medical Settings, vol. 7, no. 4, pp. 203-211.2000.

[12] A. J. Wawrzyniak, R. L. Ownby, K. McCoy, and D. Waldrop- Valverde, "Health literacy: impact on the health of hiv-infected individuals," Current HIV/AIDS Reports, vol. 10, no. 4, pp. 295-304, 2013. becomes more aggressive, vengeful, and unconsciously infecting HIV to others.

To improve health literacy and reduce the impact of low-literacy on PLWHA, researchers suggest improving the quality of message content on HIV/AIDS prevention, and intensifying and broadening the spread of information about HIV/AIDS.

[13] Kalichman SC, Benotsch E, Suarez T, Catz S, Miller J, Rompa D.Health literacy and healthrelated knowledge among persons living with HIV/AIDS. Am J Prev Med Vol 18:32531.2000 .

[14] Kalichman SC, Ramachandran B, Catz S. Adherence to combination antiretroviral therapies in HIV patients of low health literacy. J Gen Intern Med Vol .14:267-73.1999.

[15] Parker, Richard, and Angelica Basthi, Prevention Literacy: Reinventing HIV Prevention for the 21st Century, Rio de Janeiro, Brazilian Interdisciplinary AIDS Association.2015.

[16] World Health Organization (WHO). 7th Global Conference on Health Promotion, World Health Organization; 2009 [cited 2018 Pebruari 16]. Available from: http://www.who.int/healthpromotion/conference s/7gchp/en/

[17] Schenker, I Inon, HIV/AIDS and literacy: an essential component in Education for All, UNESCO. NY.2005.

[18] Nwimo, Ignatius O Dan Chinagorom Onwunaka, Sarah O. Egwu, Functional Health Literacy among People Living With HIV/AIDS: Research Findings and Directions For Future Research In Subsaharan Africa, British Journal Of Education Vol.3, No.10, Pp.58-67.2015.

[19] Thompson, Judy, The health literacy needs of women living with HIV/AIDS. Journal health sa gesondheid 1 1-2 1.2015.

[20] Corless at all,Health Literacy: Challenges to HIV Knowledge, Jacobs Journal of AIDS/HIV, Vol 1, 1-12.2015.

[21] Witte, K., \& Allen, M.. A meta-analysis of fear appeals: Implications for effective public health campaigns. Health education \& behavior, 27(5), 591-615.2000. 